\title{
The Role Of Leading Sector Labor On The GRDP Of North Sumatera Province
}

\author{
Hamni Fadlilah Nasution', Zulaika Matondang², Khoiriyah Nasution ${ }^{3}$, Dita \\ Wahyuni Nasution. 4
}

Institut Agama Islam Negeri Padangsidimpuan

Jl. H.T. Rizal Nurdin Km. 4,5 Sihitang, Padangsidimpuan

hamni@iain-padangsidimpuan.ac.id ${ }^{1}$,zulaikamatondang@iain-

padangsidimpuan.ac.id ${ }^{2}$, khoiriyahnasution23@gmail.com³ ${ }^{3}$ ditayuni682@gmail.com4

\begin{abstract}
Abstrak
Lahan pertanian yang luas membutuhkan tenaga kerja yang banyak disektor pertanian untuk meningkatkan produktivitas di sector pertanian sehingga mampu menjadi sector unggulan penopang PDRB di Provinsi Sumatera Utara, permasalahannya sector pertanian di Provinsi Sumatera Utara memiliki luas lahan terbesar namun tidak menjadi penyerap tenaga kerja terbanyak. Sehingga penelitian ini bertujuan untuk menganalisis peran tenaga kerja sector unggulan terhadap PDRB Provinsi Sumatera Utara. Jenis penelitian ini adalah kunatitatif dengan menggunakan analisis regresi data panel atau pooled data dengan menggunakan software Eviews-9. Hasil dari penelitian ini menjelaskan bahwa tenaga kerja sector unggulan berpengaruh terhadap PDRB Provinsi Sumatera Utara.
\end{abstract}

Kata Kunci : Tenaga Kerja, PDRB, Sektor Unggulan

\begin{abstract}
Extensive agricultural land requires a lot of labor in the agricultural sector to increase productivity in the agricultural sector so that it can become a leading sector to support GRDP in North Sumatra Province, the problem is that the agricultural sector in North Sumatra Province has the largest land area but is not the largest employer of labor. So this study aims to analyze the role of the leading sector workforce on the GRDP of North Sumatra Province. This type of research is qualitative using panel data regression analysis or pooled data using Eviews-9 software. The results of this study explain that the leading sector workforce has an effect on the GRDP of North Sumatra Province.
\end{abstract}

Keywords : Labor, GRDP, Leading Sectors, Pooled Data, Sector

\section{INTRODUCTION}

Labor in national development is a factor that determines the rate of economic growth both in its position as a productive workforce and a consumer (Maisaroh \& Risyanto, 2017). Labor is an important factor in the production process than other means of production (raw materials, land, water and so on) 


\section{The Role Of Leading Sector Labor On The GRDP Of North Sumatera Province}

Hamni Fadlilah Nasution, dkk

because it is human who move or operate all of these sources to produce goods of value which will later affect the amount of Gross Regional Domestic Product. (PDRB) in an area (Susanto, 2012).

Gross Regional Domestic Product based on market price is the total gross value added arising from all economic sectors in a region. Added value is the value added from a combination of production factors and raw materials in the production process. So by adding up the gross added value from each sector and adding up the gross added value from all these sectors, a Gross Regional Domestic Product will be obtained based on market prices (Central Statistics Agency, 2020). To see the development of GRDP of North Sumatra Province, it can be seen in the following table.

Table 1

North Sumatra GRDP (in Billion Rupiah)

\begin{tabular}{|c|c|}
\hline \multicolumn{1}{|l|}{ YEAR } & North Sumatra GRDP \\
\hline 2016 & $467.187,76$ \\
\hline 2017 & $491.922,92$ \\
\hline 2018 & $518.313,14$ \\
\hline 2019 & $546.168,46$ \\
\hline
\end{tabular}

In Table 1 above, it can be seen that the development of North Sumatra Province GRDP tends to increase. This increase occurred supported by an increase in the business sectors that form GRDP through 17 business sectors. However, not all sectors that are the biggest support or contributor to the GRDP value of a region, there will only be a few sectors that are the leading sectors or the biggest supporting base sector for the GRDP of a region. By determining the leading sectors, the government can find out which sectors have the potential to increase GRDP so that these sectors are prioritized, as happened in the province of North Sumatra, the biggest supporting sector for the GRDP of North Sumatra Province is the agricultural sector, this happens because the leading sectors are almost all over. The regency is the agricultural sector, this is due to the vast agricultural land in the Regency area.

There are 4 districts in North Sumatra Province that have the largest agricultural land area compared to other districts, namely Simalungun Regency, 
Deli Serdang Regency, Langkat Regency and Serdang Bedagai Regency. And it turns out that in Simalungun Regency, the largest contributor to GRDP was in the agricultural sector by 56.28 percent, and followed by Langkat Regency which was also the largest contributor to GRDP in the agricultural sector at 43.03 percent. Next is Serdang Bedagai Regency with the largest contributor to GRDP, which is the agricultural sector at 42.61 percent, while Deli Serdang Regency contributes to GDP for the agricultural sector at 11.87 percent, because the largest contributor in Deli Serdang Regency to GRDP is the processing industry sector by 30.75 percent .

Extensive agricultural land will not be optimal if it is not managed by human resources, to manage it requires labor in the agricultural sector. The development of the percentage of agricultural sector workers in North Sumatra Province can be seen in the following table.

Table 2 Percentage of Agricultural Sector Workers

\begin{tabular}{|c|c|}
\hline YEAR & THE PERCENTAGE \\
\hline 2016 & $41,30 \%$ \\
\hline 2017 & $37,52 \%$ \\
\hline 2018 & $35,53 \%$ \\
\hline 2019 & $35,54 \%$ \\
\hline
\end{tabular}

Based on data from the Central Statistics Agency, the largest percentage of agricultural sector workers in North Sumatra Province is in Nias Regency, South Nias Regency, North Nias Regency and West Nias Regency, even though the amount of agricultural land in these districts is not as large as Simalungun Regency, Langkat Regency, Deli Regency. Serdang and Serdang Bedagai Regency. Large agricultural land should require a lot of labor in the agricultural sector to increase productivity in the agricultural sector so that it can become a leading sector to support GRDP in North Sumatra Province, the problem is that the agricultural sector in North Sumatra Province has the largest land area but is not the largest employer of labor. So this study aims to analyze the role of the leading sector workforce on the GRDP of North Sumatra Province. 


\section{The Role Of Leading Sector Labor On The GRDP \\ Of North Sumatera Province}

Hamni Fadlilah Nasution, dkk

\section{LITERATURE REVIEW}

\section{Economic growth}

The economy experiences growth or development if the level of economic activity increases or higher than the previous year. In other words, the development will only occur if the amount of physical goods and services produced by the economy increases in size the following on years.Economic growth measures the achievement of the development of an economy. From one period to another the ability of a country to produce goods and services will increase. This increased capability is due to the addition of production factors both in quantity and quality. Investments will increase capital goods and the technology used will also develop. Besides that, the workforce increases as a result of population development along with the increase in their education and skills. (Deddy Rustiono, 2010). This increased capability is due to the addition of production factors both in quantity and quality. Investments will increase capital goods and the technology used will also develop. In addition, the workforce increases as a result of population development as their education and skill improve. Economic growth, the purpose of which is to evaluate the success of a region's development in a certain period of time, as seen from the growth of PDRB at constant prices.

\section{Leading Sector}

Economic growth cannot be separated from the leading sectors. Leading sectors are those that currently play a major role in the economic development of a region, because they have advantages over other sectors. Furthermore, this factor develops further through investment activities and becomes the basis of economic activity. This is based on how big the role of the sector is in the regional economy. (Maryanti \& Rasyad, t.t.)

Leading sectors are sectors or economic activities that serve both the domestic market and outside the region itself. This means that the region indirectly has the ability to export goods and services produced by the sector to other regions. Meanwhile, non-superior sectors are sectors or activities that are only able to serve the market in the area itself (Soleh \& Maryoni, 2017).

\section{Labor}


According to Law No.13 of 2003, labor is anyone capable of doing work in order to produce goods and or services both to meet their own needs and to the community. Based on Law No. 25 of 1997 concerning Manpower which was stipulated on 2 October 1998, it has been determined that the minimum age limit for a worker in Indonesia is 10 years or more. However, Indonesia does not adhere to a maximum age limit for labor because Indonesia does not yet have adequate social security.

In practical terms, the definition of labor or non-labor is only differentiated by age restrictions. Each country has a certain age limit for each worker. The purpose of determining this age limit is so that the definition given can describe the true reality. Each country chooses a different age limit because of the different labor situation in each country. (Saldy et al., T.t.)

The addition of production to produce goods and services needed by society allows an increase in the number of workers (Sukirno, 2008: 430). According to Todaro (2000: 112), the growth of the labor force is traditionally considered one of the positive factors that spur economic growth, a larger number of workers mean that it will increase the level of production (Barimbing \& Karmini, 2015). So that to spur economic growth which requires a greater number of workers, it must increase the amount of goods and services produced by the community. The number of people working depend on the size of the community demand. This demand is influenced by economic activity and wage level. The process of placement or relationship through the supply and demand of labor is called the labor market.

\section{METHODS}

\section{Time and Location of Research}

This research was conducted in North Sumatra Province specifically at the district level, this is based on the fact that the agricultural sector is more dominated by the district level than the city level in North Sumatra Province. The years studied in this study started from 2017 to 2019 as many as 25 districts in North Sumatra Province, consisting of Nias, Mandailing Natal, South Tapanuli, Central Tapanuli, North Tapanuli, Toba Samosir, Labuhan Batu, 


\section{The Role Of Leading Sector Labor On The GRDP Of North Sumatera Province}

Hamni Fadlilah Nasution, dkk

Asahan, Simalungun districts. , Dairi, Karo, Deli Serdang, Langkat, South Nias, Humbang Hasundutan, Pakpak Bharat, Samosir, Serdang Bedagai, Batubara, North Padang Lawas, Padang Lawas, South Labuhan Batu, North Labuhan Batu, North Nias, West Nias.

\section{Data types and sources}

This research was conducted with quantitative research methods, which are methods used to test certain theories by examining the relationship between variables which produces data in the form of numbers so that it can be analyzed based on statistical procedures (Noor, 2015). This study uses secondary data, where secondary data is obtained from the link www.bps.go.id which is the official link of the Indonesian Statistics Agency and https://sumut.bps.go.id/ which is the official link of the Central Statistics Agency of North Sumatra Province.

\section{Population and Sample}

From the start, it is necessary to identify the population precisely and accurately, if the population is not clearly known, the resulting conclusions may be wrong. Population consists of objects or subjects that have certain quantities and characteristics, so the population is not only people, but also objects and other objects, not just the number of objects / subjects studied but includes all the characteristics / properties possessed by the subject or object that is studied it (Sugiyono, 2017). So that the population in this study is all districts in North Sumatra Province, as many as 25 districts from 2017 to 2019 as many as 75 populations. The sample is part of a population that includes a selected number of members of the population. The sampling technique in this study is saturated sampling, where all the population is sampled as many as 75 samples.

\section{Data Analysis Techniques}

This research uses Eviews-9 software in data processing. This type of research is a cross section regression of panel data or pooled data. In simple terms, panel data can be defined as a data set in which the behavior of crosssectional units (eg: individuals, companies, countries) is observed over time (Ghozali \& Ratmono, 2013). In the panel data, there are three models produced, namely the common effect, fixed effect and random effect, however, of the three models, only one will be selected for the next assumption. Selection of the best 
model is done through several tests, including the chow test to choose the best model between the common effect or fixed effect model, if the selected result is a common effect model, then that is the model we will use, but if the selected result is fixed effect then the test is continued on the Hausman test.

The Hausman test is used to select the best model between the fixed effect model and the random effect model, if the selected test result is a fixed effect model then this is the model we will use, but if the selected model is a random effects model then the testing must proceed to the next step namely the Lagrange Multiplier (LM) test. The LM test is used to select the best model between the random effect model and the common effect model. A good study is one whose data is normally distributed using the Jarque Berra test. And to determine whether or not the influence of the independent variable on the dependent variable is used a hypothesis test consisting of the T-test and the coefficient of determination test.

\section{DISCUSSION}

\section{Description of Research Data}

This research was conducted in North Sumatra Province with the object of research being all districts in North Sumatra Province as many as 25 districts, the data needed in the study are Gross Regional Domestic Product (GRDP) data and data on the percentage of agricultural sector workers from 2017 to 2019, can be seen in the following table.

Table 3

Research data

\begin{tabular}{|l|c|c|c|c|c|c|}
\hline \multirow{2}{*}{\multicolumn{1}{|c|}{ District }} & \multicolumn{3}{|c|}{ GRDP (Billion Rp) } & \multicolumn{3}{c|}{ The Percentage } \\
\cline { 2 - 7 } & $\mathbf{2 0 1 7}$ & $\mathbf{2 0 1 8}$ & $\mathbf{2 0 1 9}$ & $\mathbf{2 0 1 7}$ & $\mathbf{2 0 1 8}$ & $\mathbf{2 0 1 9}$ \\
\hline Nias & $2.325,01$ & $2.440,16$ & $2.563,03$ & 80,65 & 83,76 & 78,48 \\
\hline Mandailing Natal & $8.416,50$ & $8.904,14$ & $9.376,46$ & 46,16 & 44,96 & 48,80 \\
\hline South Tapanuli & $8.748,18$ & $9.201,96$ & $9.683,66$ & 64,44 & 57,75 & 60,45 \\
\hline Southeast Tapanuli & $6.3448,44$ & $6.678,25$ & $7.024,15$ & 47,34 & 44,41 & 54,39 \\
\hline North Tapanuli & $5.280,69$ & $5 \cdot 510,19$ & $5.764,94$ & 65,91 & 67,80 & 60,39 \\
\hline Toba Samosir & $5.001,43$ & $5.249,25$ & $5.505,26$ & 57,53 & 49,31 & 55,36 \\
\hline Labuhan Batu & $21.048,17$ & $\mathbf{2 2 . 1 1 2 , 3 4}$ & $\mathbf{2 3 . 2 3 2 , 7 1}$ & 44,54 & 38,27 & 42,65 \\
\hline
\end{tabular}




\section{The Role Of Leading Sector Labor On The GRDP Of North Sumatera Province}

Hamni Fadlilah Nasution, dkk

\begin{tabular}{|l|c|c|c|c|c|c|}
\hline Asahan & $23.525,35$ & $24.844,87$ & $26.245,24$ & 36,12 & 36,30 & 33,39 \\
\hline Simalungun & $24.715,67$ & $25.996,21$ & $27.348,70$ & 54,60 & 50,69 & 45,30 \\
\hline Dairi & $5 \cdot 968,81$ & $6.267,82$ & $6.569,81$ & 71,78 & 70,95 & 70,00 \\
\hline Karo & $13.145,85$ & $13.744,17$ & $14.376,28$ & 67,22 & 64,90 & 61,88 \\
\hline Deli Serdang & $64.991,87$ & $68.341,00$ & $71.878,69$ & 15,65 & 15,34 & 12,61 \\
\hline Langkat & $26.822,60$ & $28.170,08$ & $29.597,77$ & 35,89 & 32,92 & 42,67 \\
\hline South Nias & $3.826,62$ & $4.018,74$ & $4.221,04$ & 85,66 & 78,43 & 77,32 \\
\hline Humbanghasundutan & $3 \cdot 756,66$ & $3.946,12$ & $4.141,10$ & 77,08 & 76,17 & 68,45 \\
\hline Pakpak Bharat & 760,55 & 805,01 & 852,30 & 76,31 & 76,96 & 64,27 \\
\hline Samosir & $2.776,85$ & $2.931,70$ & $3.098,74$ & 64,45 & 59,70 & 63,41 \\
\hline Serdang Bedagai & $17.516,43$ & $18.421,38$ & $19.393,39$ & 42,00 & 39,00 & 42,01 \\
\hline Batubara & $22.034,26$ & $22.998,60$ & $23.998,59$ & 38,08 & 38,43 & 36,81 \\
\hline North Padang Lawas & $7 \cdot 378,98$ & $7.791,05$ & $8.228,45$ & 64,88 & 63,16 & 69,59 \\
\hline Padang Lawas & $7.110,25$ & $7.534,30$ & $7.959,31$ & 57,59 & 57,88 & 52,57 \\
\hline South Labuhan Batu & $16.907,59$ & $17.797,95$ & $18.750,16$ & 60,46 & 56,82 & 61,02 \\
\hline North Labuhan Batu & $15.602,05$ & $16.413,33$ & $17.259,19$ & 50,78 & 51,25 & 46,08 \\
\hline North Nias & $2.134,49$ & $2.228,75$ & $2.332,44$ & 77,92 & 71,02 & 68,11 \\
\hline West Nias & $1.126,19$ & $1.179,91$ & $1.236,73$ & 86,97 & 79,10 & 74,91 \\
\hline
\end{tabular}

Source : central stathistic North Sumatera Province

Table 4

Description of Research Data

\begin{tabular}{|l|l|l|}
\hline & GRDP & Labor \\
\hline Mean & 13352.35 & 56.88280 \\
\hline Median & 7959.310 & 57.88000 \\
\hline Maximum & 71878.69 & 86.97000 \\
\hline Minimum & 760.5500 & 12.61000 \\
\hline Std. Dev. & 14153.51 & 16.75269 \\
\hline Sum & 1001426. & 4266.210 \\
\hline Sum Sq. Dev. & $1.48 \mathrm{E}+10$ & 20768.29 \\
\hline & & \\
\hline Observations & 75 & 75 \\
\hline
\end{tabular}

From table 2 above, the maximum value for GRDP of $71,878.69$ (in billion Rupiah) is in Deli Serdang Regency, while for the percentage of agricultural sector workers, the minimum is 12.61 percent. This is because the largest contributor to the business sector in Serdang Bedagai Regency is not in the agricultural sector, but the first largest contributor is in the manufacturing sector, amounting to $22,107,680.12$ (in million Rupiah), followed by the wholesale and retail trade sector; repairs of cars and motorbikes amounting to 12,299,619.97 (in million Rupiah), and the third support for GRDP is the construction sector of 10,983,270.94 (in million Rupiah), and the agricultural sector is in fourth place to support the GRDP for Deli Serdang Regency.

Table 2 above shows that the maximum percentage value of agricultural sector workers is in West Nias Regency, but the value of its GRDP is the second smallest contributor to the GRDP of North Sumatra Province, while 
the smallest contributor to GRDP is in North Sumatra Province, namely in Pakpak Bharat Regency with a value of 760.55 ( in Million Rupiah).

\section{Panel Data Model (Pooled Data)}

\section{Common Effect Model}

Table 5

\section{Common Effect}

Dependent Variable: PDRB

Method: Panel Least Squares

Date: 11/08/20 Time: 18:48

Sample: 20172019

Periods included: 3

Cross-sections included: 25

Total panel (balanced) observations: 75

\begin{tabular}{lllll}
\hline \hline Variable & Coefficient & Std. Error & t-Statistic & Prob. \\
\hline \hline C & 53033.56 & 3305.894 & 16.04212 & 0.0000 \\
Labor & -697.5959 & 55.77979 & -12.50625 & 0.0000 \\
\hline \hline
\end{tabular}

\section{Model Fixed Effect}

Table 6

Fixed Effect

Dependent Variable: PDRB

Method: Panel Least Squares

Date: 11/08/20 Time: 18:49

Sample: 20172019

Periods included: 3

Cross-sections included: 25

Total panel (balanced) observations: 75

\begin{tabular}{lllll}
\hline \hline Variable & Coefficient & Std. Error & t-Statistic & Prob. \\
\hline \hline C & 16041.69 & 2070.015 & 7.749554 & 0.0000 \\
Labor & -47.27871 & 36.33815 & -1.301076 & 0.1993 \\
\hline \hline
\end{tabular}




\section{The Role Of Leading Sector Labor On The GRDP Of North Sumatera Province}

Hamni Fadlilah Nasution, dkk

\section{Model Random Effect}

\section{Table 7 \\ Random effect}

Dependent Variable: PDRB

Method: Panel EGLS (Cross-section random effects)

Date: 11/08/20 Time: 18:49

Sample: 20172019

Periods included: 3

Cross-sections included: 25

Total panel (balanced) observations: 75

Swamy and Arora estimator of component variances

\begin{tabular}{lllll}
\hline \hline Variable & Coefficient & Std. Error & t-Statistic & Prob. \\
\hline \hline C & 20734.10 & 2505.648 & 8.274942 & 0.0000 \\
Labor & -129.7712 & 34.03887 & -3.812442 & 0.0003 \\
\hline \hline
\end{tabular}

\section{Model Selection}

\section{Chow test}

\section{Table 8}

\section{Chow test}

Redundant Fixed Effects Tests

Equation: Untitled

Test cross-section fixed effects

\begin{tabular}{llll}
\hline \hline Effects Test & Statistic & d.f. & Prob. \\
\hline \hline Cross-section F & 209.184268 & $(24,49)$ & 0.00oo \\
Cross-section Chi-square & 347.937140 & 24 & 0.0000 \\
\hline \hline
\end{tabular}

From the results of the chow test above, it can be explained from the cross-section probability value $\mathrm{F}$ is $0.0000<0.05$, which means that the selected model is a fixed effect model, because the selected model is a fixed effect model, then the next test is carried out, namely the Hausman test.

\section{Hausman Test}

\section{Tabel 9 \\ Hausman test}

Correlated Random Effects - Hausman Test

Equation: Untitled

Test cross-section random effects

\begin{tabular}{lll}
\hline \hline & Chi-Sq. & \\
Test Summary & Statistic & Chi-Sq. d.f. $\quad$ Prob. \\
\hline \hline
\end{tabular}


From the results of the Hausman test above, it can be explained from the random cross-section probability value with a value of $0.1466>0.05$, which means that the selected model is a random effect model. Because the selected model is a random effect model, the next test is carried out, namely the Lagrange Multiplier (LM) test.

\section{Lagrange Multiplier test (LM)}

\section{Table 10}

Lagrange Multiplier test

\begin{tabular}{|c|c|c|c|}
\hline & $\begin{array}{l}\text { Test Hypothe } \\
\text { Cross-section }\end{array}$ & Time & Both \\
\hline Breusch-Pagan & $\begin{array}{l}59.50555 \\
(0.0000)\end{array}$ & $\begin{array}{l}1.276392 \\
(0.2586)\end{array}$ & $\begin{array}{l}60.78195 \\
(0.0000)\end{array}$ \\
\hline Honda & $\begin{array}{c}7.713984 \\
(0.0000)\end{array}$ & $\begin{array}{l}-1.129775 \\
--\end{array}$ & $\begin{array}{c}4.655739 \\
(0.0000)\end{array}$ \\
\hline King-Wu & $\begin{array}{c}7.713984 \\
(0.0000)\end{array}$ & $\begin{array}{l}-1.129775 \\
--\end{array}$ & $\begin{array}{l}1.054021 \\
(0.1459)\end{array}$ \\
\hline Standardized Honda & $\begin{array}{l}8.067751 \\
(0.0000)\end{array}$ & $\begin{array}{l}-0.882959 \\
--\end{array}$ & $\begin{array}{l}1.344064 \\
(0.0895)\end{array}$ \\
\hline Standardized King-Wu & $\begin{array}{l}8.067751 \\
(0.0000)\end{array}$ & $\begin{array}{l}-0.882959 \\
--\end{array}$ & $\begin{array}{l}-1.109643 \\
--\end{array}$ \\
\hline Gourierioux, et al.* & -- & -- & $\begin{array}{l}59.50555 \\
(<0.01)\end{array}$ \\
\hline \multicolumn{4}{|c|}{ *Mixed chi-square asymptotic critical values: } \\
\hline $\begin{array}{l}1 \% \\
5 \% \\
10 \%\end{array}$ & $\begin{array}{l}7.289 \\
4.321 \\
2.952\end{array}$ & & \\
\hline
\end{tabular}

From the table above, the LM test results can be explained by looking at the probability of the Breusch-Pagan value, namely $0.0000<0.05$, which means that the selected model is a random effect model, so for the next step in analyzing the results of hypothesis testing we use a random effect model.

\section{Normality test}

The normality test aims to test the research data, both the dependent variable and the independent variable, whether normally distributed or not, because good 


\section{The Role Of Leading Sector Labor On The GRDP Of North Sumatera Province}

Hamni Fadlilah Nasution, dkk

research is research where the data is normal. The normality test of this study used the Jaque-Berra test with a significance level of 5 percent. The normality test of this research variable can be seen in the following figure.

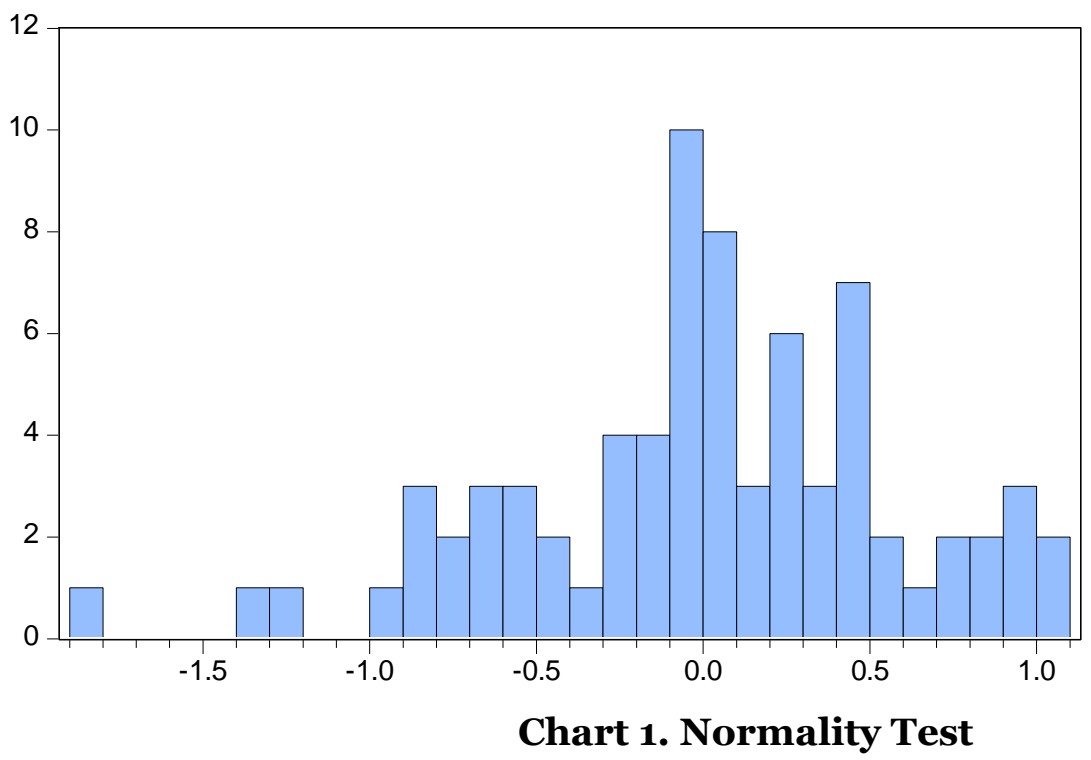

Series: Standardized Residuals Sample 20172019

Observations 75

Mean $\quad 2.40 \mathrm{e}-15$

Median $\quad 0.014371$

Maximum $\quad 1.047732$

Minimum $\quad-1.872102$

Std. Dev. $\quad 0.582801$

Skewness $\quad-0.548614$

Kurtosis $\quad 3.482577$

Jarque-Bera $\quad 4.489965$

Probability $\quad 0.105929$

The normality test image above can be explained by looking at the JarqueBernya probability value of 0.105929 , meaning that the data in this study are normally distributed because the probability value is $>0.05$.

\section{Hypothesis testing}

Hypothesis testing aims to determine how far the research hypothesis can be accepted based on the data that has been collected. Hypothesis testing is carried out not to test the truth of the hypothesis, but to test whether the hypothesis is accepted or rejected. Hypothesis testing consists of a partial test in the form of a t-test and a test of the coefficient of determination. The results of this research hypothesis test can be seen in the following table.

Table 11

Research Hypothesis Test

\begin{tabular}{|c|c|c|c|}
\hline Hipotesis test & The test used & Prob. & Decision \\
\hline \multirow[t]{2}{*}{ Labor to GRDP } & t-test & \multirow{2}{*}{0,0003} & \multirow{2}{*}{ Has effect } \\
\hline & $-3,812442$ & & \\
\hline Determination coefficient & R-Square & 0,113033 & 11,30 percent \\
\hline
\end{tabular}

Source : processed data 
Based on the table above, it can be explained that the superior sector workforce has an effect on GRDP, which is seen from the T-test results with an influence level of 11.30 percent seen from the coefficient of determination.

\section{The Role of Leading Sector Workers in GRDP in North Sumatra Province}

After regional autonomy, each region is free to determine prioritized sectors to be developed by looking at which sectors have weaknesses and advantages through a sectoral approach. Until now, the sectoral approach is one of the strategies used in regional development with more emphasis on selecting economic sectors that can more precisely and quickly act as a driver of the regional economy, absorbing labor and alleviating poverty. According to (Syaiful, 2014), the sectoral approach is more focused on efforts to increase the productivity of the economic sector through development priorities in regional policies. So that the analysis of the sectors that are the basis / economic advantage is very important as a consideration in formulating development policies to find out which sectors are the base sectors and have the biggest role in driving economic growth in a region. As in North Sumatra province, the leading sector for the Regency is the agricultural sector and is supported by the extent of agricultural land in the Regency area.

The extent of agricultural land in the Regency of North Sumatra Province is one of the leading sector supporters for business fields in the agricultural sector. The extent of agricultural land will actually open up employment in the agricultural sector. The absorption of labor that is not followed by additional input will cause the output of agricultural products to decrease, for this reason the government needs to provide capital for farmers, conduct training and introduce new technologies or innovations in agriculture, the aim is to provide added value to the output of GRDP in the agricultural sector (Kristiana , 2015).

The results of the study explained that the leading sector workforce had an effect on GRDP in North Sumatra Province with the equations formed were:

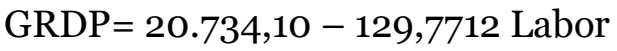

From the above equation, it can be explained that if the leading sector workforce is not there, the total GRDP of North Sumatra Province is worth 20,734.10 (in billion Rupiah), but if the leading sector workforce has increased by one unit, then the GRDP of North Sumatra Province will decrease by 129.7712 percent. This is not in accordance with the statement that labor is one of the most decisive factors in the development process of an area which is marked by an increase in GRDP (Sayifullah \& Emmalian, 2018), because the increasing number of workers is also supported by the addition of 


\section{The Role Of Leading Sector Labor On The GRDP Of North Sumatera Province}

Hamni Fadlilah Nasution, dkk

agricultural land area. the agricultural sector has also increased and the GRDP can also increase.

The results of this study are different from the theory, where an increase in the workforce of the leading sectors can actually reduce the GRDP value of North Sumatra Province, this is because all districts in North Sumatra Province, the leading sectors are in the agricultural sector, so that the largest contributor to GRDP in each district is agricultural sector, but not in line with the percentage of agricultural sector workers. This can be explained, in some districts that have large agricultural land areas that are not in line with the number of workers in the agricultural sector, and there are areas where agricultural land is less extensive, but the percentage of labor in the agricultural sector is almost entirely farmers, so that many farmers are unemployed, resulting in productivity decreases, this explains that if the workforce in the agricultural sector has increased, it will actually reduce GDP. Districts whose land is large even though the percentage of the workforce is not large if the agricultural sector workforce is supported by agricultural technology and modern agricultural training can actually increase productivity.

Islam also regulates labor, Islam overhauls various discriminatory systems by providing various alternative solutions, including in the field of labor. Research results (Aravik, 2018) show that Islam views workers as you who must be treated as best as possible by your employer. Islam provides a broad view of human life, including the management of an economy. Included in the concept of labor, from an Islamic point of view, it contains ethical values inherent in its governance. Islam even places labor as a core part of economic activity, which plays a role in value creation or wealth creation (Syed \& Ali, 2010). Work as an activity that makes humans productive and valuable in the eyes of Allah and His Messenger as well as in the eyes of society as stated by Ibn Khaldun, that work is an implementation of the function of the human caliphate which is manifested in producing a certain value arising from the results of work (Hijriah \& Adiba, 2019).

According to (Huda, 2010) Islam views work as an element of production based on the concept of istikhlaf, where humans are responsible for the prosperity of the world and are also responsible for investing and developing assets mandated by Allah to cover human needs, while labor is all efforts and endeavors that are made. by the body or mind in order to get the reward they deserve. The unity of work and labor in managing God's mandate responsibly and being able to produce something that brings benefits or maslahah. An Islamic economic actor will be oriented towards 
seeking maximum maslahah, therefore they do not only consider the benefits of the work done, but also the content of the blessings in the work concerned.

\section{CONCLUSION}

The number of workers in leading sectors is not necessarily able to increase productivity which can increase and become the largest contributor to the GRDP of North Sumatra Province. We can see this in 4 districts in North Sumatra Province with the most extensive agricultural land, namely Simalungun Regency, followed by Deli Serdang Regency, Langkat Regency and Serdang Bedagai Regency, while the percentage of labor in the agricultural sector is small. With the use of technology in agriculture and supported by the role of local governments, the small percentage of the agricultural sector workforce is not a problem in helping to increase its GRDP. In addition, the role of labor in Islam is to manage the natural resources that Allah has given to humans, so that they can be utilized by other humans through production, where abundant production will provide prosperity for an area.

\section{REFERENCES}

Aravik, H. (2018). Konsep Buruh dalam Perspektif Islam. Islamic Banking : Jurnal Pemikiran dan Pengembangan Perbankan Syariah, 4(1), 1-10. https://doi.org/10.36908/isbank.v4i1.50

Badan Pusat Statistik. (2020). Produk Domestik Regional Bruto (PDRB) Atas Dasar Harga Pasar. https://www.bps.go.id/subject/52/produk-domestik-regionalbruto--lapangan-usaha-.html

Barimbing, Y. R., \& Karmini, N. L. (2015). PENGARUH PAD, TENAGA KERJA, DAN INVESTASI TERHADAP PERTUMBUHAN EKONOMI DI PROVINSI BALI. 4(5), 17.

Ghozali, I., \& Ratmono, D. (2013). ANALISIS MULTIVARIAT DAN EKONOMETRIKA : Teori, Konsep, dan Aplikasi Dengan Eviews 8. Universitas Diponegoro Semarang.

Hijriah, H. Y., \& Adiba, E. maya. (2019). The Labor Market: An Overview from an Islamic Perspective. The International Journal of Applied Business Tijab, 3(1), 24-37.

Huda, N. (2010). Lembaga Keuangan Islam: Tinjauan Teoritis dan Praktis. Kencana. Kristiana, Y. P. (2015). Analisis Pengeluaran Pemerintah, Tenaga Kerja dan Kebijakan RENSTRA Terhadap PDRB Sektor Pertanian. Economics Development Analysis Journal, 4(4), 452-459. 


\section{The Role Of Leading Sector Labor On The GRDP Of North Sumatera Province}

Hamni Fadlilah Nasution, dkk

Maisaroh, M., \& Risyanto, H. (2017). Pengaruh Investasi, Pengeluaran Pemerintah, dan Tenaga Kerja Terhadap PDRB Provinsi Banten. Ekbis: Jurnal Ekonomi dan Bisnis, 1(2), 206-221.

Maryanti, S., \& Rasyad, R. (t.t.). ANALISIS SEKTOR UNGGULAN TERHADAP KINERJA EKONOMI DALAM MENYERAP TENAGA KERJA DI KOTA PEKANBARU. 15.

Noor, J. (2015). METODOLOGI PENELITIAN: SKRIPSI, TESIS, DISERTASI, DAN KARYA ILMIAH Edisi Pertama. Kencana.

Saldy, T. G., Waidah, D. F., Silitonga, T., \& Pangestu, P. (t.t.). ANALISIS TENAGA KERJA TERHADAP KEGIATAN SEKTOR EKONOMI DALAM PERENCANAAN KOTA KABUPATEN KARIMUN. 10.

Sayifullah, \& Emmalian. (2018). Pengaruh Tenaga Kerja Sektor Pertanian dan Pengeluaran Pemerintah Sektor Pertanian Terhadap Produk Domestik Bruto Sektor Pertanian di Indonesia. Jurnal Ekonomi-Qu, 8(1), 66-81.

Soleh, A., \& Maryoni, H. S. (2017). ANALISIS SEKTOR EKONOMI UNGGULAN DAN HUBUNGANNYA DENGAN KESEMPATAN KERJA DAN INVESTASI DI KABUPATEN BATANGHARI. Jurnal Ekonomi-Qu, $7(1)$. https://doi.org/10.35448/jequ.v7i1.4183

Sugiyono. (2017). STATISTIKA UNTUK PENELITIAN. Alfabeta.

Susanto, A. (2012). Analisis Angkatan Kerja dan Kontribusinya Terhadap Produk Domestik Regional Bruto (PDRB) Jawa Tengah Tahun 2010 Dengan Aplikasi Sistem Informasi Geografis. Universitas Muhammadiyah Surakarta.

Syaiful, dkk. (2014). Analisis Sektor Basis Dalam Hubungannya Dengan Penyerapan Tenaga Kerja Di Kabupaten Batang Hari. Jurnal Perspektif Pembiayaan dan Pembangunan Daerah Universitas Jambi, 2(1).

Syed, J., \& Ali, A. J. (2010). Principles of Employment Relation in Islam: A Normative View. Employee Relations, 32(5), 454-469. 